EMSP, DE-FG07-00ER15119

Final Report, July 2003

\title{
Microbially Modified Immobilization of Contaminants Through In Situ Biostimulation
}

\author{
Scott Fendorf \\ Dept. of Geological and Environmental Sciences \\ Stanford University \\ Stanford, CA 94305 \\ Phone: $650-723-5238$ \\ Email: fendorf@stanford.edu
}

\section{INTRODUCTION}

Bacteria have an important role in the biogeochemical cycling of uranium by catalyzing the reduction of soluble $\mathrm{U}(\mathrm{VI})$ to insoluble $\mathrm{U}(\mathrm{IV})$, a process that has received considerable attention as a potential remediation option. A number of microorganisms \{e.g., Geobacter metallireducens (Lovley et al. 1991), Shewanella alga (Caccavo et al. 1992), Shewanella putrefaciens (Lovley et al. 1991), Desulfovibrio desulfuricans (Lovley and Phillips 1992a; Lovley and Phillips 1992b), Desulfovibrio vulgaris (Lovely et al. 1993), and Desulfovibrio baculatus (Barton et al. 1996)\} enzymatically reduce $\mathrm{U}(\mathrm{VI})$, where U(VI) acts as the terminal electron acceptor during anaerobic respiration (Lovley et al. 1991).

In most natural environments, a multitude of metabolic substrates are present simultaneously. Organisms that can utilize uranium as a metabolic substrate for respiration also may have the ability to use a variety of other oxidized substrates as electron acceptors. Thus, these substrates are, in effect, competing for electrons that are being passed through the electron transport chain during respiration. To assess the feasibility of in situ immobilization of uranium in subsurface environments and to understand the cycling of uranium, it is necessary to discern the chemical and/or biological conditions dictating which terminal electron acceptor(s) will be utilized.

Found predominantly as (hydr)oxide solids, Fe(III) is one of the most important electron acceptors for bacterial respiration in natural systems. Iron(III) is ubiquitous in surface and subsurface environments and in some systems (anaerobic) can comprise the largest mass of oxidant for microbial respiration on organic compounds (Heron et al. 1994). Therefore, Fe may impose severe competition on $\mathrm{U}(\mathrm{VI})$ for bacterial respiratory reduction.

On the basis of energy yields, one may expect bacteria to utilize the most energetically favorable terminal electron acceptor until that substrate is exhausted and only then utilize the next most favorable substrate. In anoxic environments, bacteria are expected to preferentially utilize $\mathrm{NO}_{3}{ }^{-}, \mathrm{Mn}$ (IV), $\mathrm{Fe}(\mathrm{III})$ and then $\mathrm{SO}_{4}{ }^{2-}$ (Nealson and Saffarini 1994) (Lovley 1991). Uranyl (present as $\mathrm{UO}_{2}\left(\mathrm{CO}_{3}\right)_{3}{ }^{4-}$ or $\mathrm{UO}_{2} \mathrm{OH}^{+}$) is expected to fall between $\mathrm{Mn}(\mathrm{IV})$ and $\mathrm{Fe}(\mathrm{III})$ on this continuum. When both Fe (as ferrihydrite) and $\mathrm{U}$ 
(as a soluble hydroxide or carbonate species) are present, $\mathrm{U}(\mathrm{VI})$ is the more energetically favorable substrate (Eqn. 1-3).

$$
\begin{aligned}
& \mathrm{C}_{3} \mathrm{H}_{5} \mathrm{O}_{3}{ }^{-}+2 \mathrm{UO}_{2}\left(\mathrm{CO}_{3}\right)_{3}{ }^{4-}+\mathrm{H}^{+}+2 \mathrm{H}_{2} \mathrm{O} \rightarrow \mathrm{C}_{2} \mathrm{H}_{3} \mathrm{O}_{2}{ }^{-}+7 \mathrm{HCO}_{3}{ }^{-}+2 \mathrm{UO}_{2} \\
& \Delta \mathrm{G}_{\mathrm{rxn}} *=-297 \mathrm{~kJ} / \mathrm{mol} \text { lactate } \\
& \mathrm{C}_{3} \mathrm{H}_{5} \mathrm{O}_{3}^{-}+2 \mathrm{UO}_{2} \mathrm{OH}^{+} \rightarrow \mathrm{C}_{2} \mathrm{H}_{3} \mathrm{O}_{2}^{-}+\mathrm{HCO}_{3}^{-}+2 \mathrm{UO}_{2}+3 \mathrm{H}^{+} \\
& \Delta \mathrm{G}_{\mathrm{rxn}} *=-183 \mathrm{~kJ} / \mathrm{mol} \text { lactate } \\
& \mathrm{C}_{3} \mathrm{H}_{5} \mathrm{O}_{3}^{-}+4 \mathrm{Fe}(\mathrm{OH})_{3}+7 \mathrm{H}^{+} \rightarrow \mathrm{C}_{2} \mathrm{H}_{3} \mathrm{O}_{2}^{-}+\mathrm{HCO}_{3}^{-}+4 \mathrm{Fe}^{2+}+10 \mathrm{H}_{2} \mathrm{O} \\
& \Delta \mathrm{G}_{\mathrm{rxn}} *=-47 \mathrm{~kJ} / \mathrm{mol} \text { lactate }
\end{aligned}
$$

In fact, more than three-times as much energy is available when U(VI) is used as an electron acceptor compared to Fe(III) in ferrihydrite. The solubility of metabolic substrates can also affect bioavailability and utilization, as soluble substrates are more easily accessible to organisms than solid phase substrates (Lovley 1991). Due to their low solubilities (e.g. $\log \mathrm{K}$ for ferrihydrite is $-39 \pm 0.7$ (Cornell and Schwertman 1996)), Fe(III) minerals are believed to be available to bacteria in solid form only; in contrast to iron, U(VI) is available in soluble form. Therefore, based on solubility considerations and on energy yields, one may expect U(VI) to be preferentially utilized over ferric (hydr)oxides. However, the above considerations alone generally do not fully predict substrate utilization.

Recent studies demonstrate that $\mathrm{U}(\mathrm{VI})$ reduction decreases in the presence of amorphous $\mathrm{Fe}$ and Mn hydroxides, such as ferrihydrite (Wielinga et al. 2000; Nevin and Lovley 2000), Mn-oxides (Liu et al. 2002), and Fe containing sediments (Nevin and Lovley 2000). These studies attributed the observed decrease in $\mathrm{U}(\mathrm{VI})$ reduction to terminal electron acceptor competition, abiotic re-oxidation, and substrate availability. Additional factors to consider are microbial adhesion and biofilm production, which may also be important for understanding substrate competition and are the focus of this study.

Particularly relevant to this study is the attachment of bacteria to surfaces that are utilized as a metabolic substrate, such as iron oxides. Because Fe-oxides form highly insoluble minerals, the rate and extent of utilization of these minerals by bacteria are limited by availability of (access to) Fe(III) in natural systems. While contact with iron oxides appears to be influential in Fe(III) reduction (Caccavo et al. 1996; Lovley and Phillips 1988; Caccavo et al. 1992; Das and Caccavo 2000), cytochromes and/or quinones released from the cells can act as electron shuttles and thus facilitate indirect interactions between the cell and mineral surface (Newman and Kolter 2000). Neverthess, attachment to the mineral surface is beneficial and important for bacterial respiration on iron oxides and, in fact, most iron reducing organisms rapidly attach to oxide surfaces (Caccavo and Das 2002).

Bacterial biofilms can grow to be hundreds of microns thick, with complex internal structure made up of cells and extracellular polymeric substances (EPS), thus limiting and/or controlling the movement of soluble chemical species. In developing and living biofilms, it is well established that chemical gradients (nutrient, oxygen, $\mathrm{pH}$, temperature and light) are formed and maintained within the biofilm structure (Allan et al. 1999; Schramm et al. 2000; Vroom et al. 1999). Gradients are caused by utilization of substrates diffusing into and products diffusing out of the biofilm matrix. Chemical gradients may limit substrate availability in certain regions of the biofilm-distinct microenvironments rapidly form that can dictate metabolic pathways (e.g., which electron donor or electron acceptor is used). Analogous gradients of metabolic activity have also been observed in microbial biofilms (Kinniment and Wimpenny 1992). Cells toward the outside of the biofilm are closer to the source of nutrients and substrates and can maintain high metabolic activity, whereas cells toward the center of the biofilm are limited by low nutrient/substrate levels. Thus, in certain regions of the biofilm, cells operate at reduced or nominal biochemical activity. Here we explore microbial U(VI) reduction in the presence of Fe(III) with a specific focus on the effects biofilm formation and EPS production have on terminal electron acceptor selection. 


\section{EXPERIMENTAL METHOD}

In order to determine competitive (or synergistic) effects between Fe(III) and U(VI) respiration, we examined utilization of simultaneously available electron acceptors, soluble U(VI) and solid-phase $\mathrm{Fe}(\mathrm{III})$ (as ferrihydrite). Electron acceptors studied were U(VI), added as uranyl acetate, and Fe(III), present as a short-range order iron oxide (ferrihydrite). Utilization was measured by comparing (i) rates of terminal electron acceptor reduction and (ii) total electrons transferred. Reaction kinetics further provide the ability to elucidate differences in reduction mechanisms and were coupled with direct microscopic examination of the bacterial assemblage.

Cell and Media Preparation: Shewanella alga strain BrY (ATCC \# 51181) and Shewanella putrefaciens strain CN32 (ATCC \# 8071) were grown to late log phase in tryptic soy broth (TSB, DIFCO, Detroit, MI) at $32^{\circ} \mathrm{C}$ and frozen back in $20 \%$ glycerol at $-80^{\circ} \mathrm{C}$. Seed cultures were started from frozen stocks. Separate cell suspensions of $S$. alga and $S$. putrefaciens were prepared by growing the microbes aerobically on TSB at $30^{\circ} \mathrm{C}(S$. alga $)$ and $25^{\circ} \mathrm{C}$ (S. putrefaciens) to late log phase, transferring $1 \mathrm{~mL}$ of cells to $100 \mathrm{~mL}$ of new media, and growing again to late log phase. Cells were harvested by centrifugation $(6000 \mathrm{~g}, 10 \mathrm{~min})$, washed twice in sterile anaerobic bicarbonate buffer $\left(2.5 \mathrm{~g}\right.$ of $\mathrm{NaHCO}_{3} / \mathrm{L}$, $\mathrm{pH}$ 7.0), and resuspended in the buffer solution in sterile serum vials. Serum vials were purged with an $80: 20 \mathrm{~N}_{2}: \mathrm{CO}_{2}$ headspace and capped with thick butyl rubber stoppers. Cell suspensions were stored on ice for less than 15 minutes before inoculation into batch cultures.

Reduction studies were conducted in batch cultures under non-growth conditions with $50 \mathrm{~mL}$ of anaerobic bicarbonate buffered media. Non-growth conditions were used to simplify kinetic studies and to eliminate phosphate interference with the colorimetric method used to measure U(VI) (described below). Uranyl reduction was studied with and without ferrihydrite amendments. Ferrihydrite was synthesized by titration of $\mathrm{FeNO}_{3} \cdot 9 \mathrm{H}_{2} \mathrm{O}(0.4 \mathrm{mM})$ with $1 \mathrm{M} \mathrm{NaOH}$ to $\mathrm{pH} 7$ as described by Ryden et al. (Ryden et al. 1987). The media contained the following components in $\mathrm{g} / \mathrm{L}: \mathrm{NaHCO}_{3}, 2.5 ; \mathrm{NH}_{4} \mathrm{Cl}, 1.5$; $\mathrm{KCl}, 0.1 ; \mathrm{CaCl}_{2}, 0.1$ and $10 \mathrm{~mL}$ of Wolfe's minerals solution (Balch et al. 1979). Lactate was added to a final concentration of $10 \mathrm{mM}$. Media was boiled and cooled under $80: 20 \mathrm{~N}_{2}: \mathrm{CO}_{2}$, brought to $\mathrm{pH}$, and equilibrated with 80:20 $\mathrm{N}_{2}: \mathrm{CO}_{2}$ overnight. For experiments with iron hydr(oxide) amendments, minerals were added to $60 \mathrm{~mL}$ serum vials prior to the media. The media was dispensed into serum vials, purged with 80:20 $\mathrm{N}_{2}: \mathrm{CO}_{2}$, capped with thick butyl rubber stoppers, and immediately autoclaved. Sterile, anaerobic uranyl acetate (adjusted to $\mathrm{pH} 4.9$ ) was added aseptically to serum vials with $\mathrm{N}_{2}$ purged needles and syringes to reach a final concentration of $1.5 \mathrm{mM}$. To allow for sorption, suspensions were allowed to react for $24 \mathrm{~h}$ before microbial inoculation. The $\mathrm{pH}$ of all vials remained between 6.7 and 7.1 throughout the reaction. Cells were added to vials in $1 \mathrm{~mL}$ aliquots with $\mathrm{N}_{2}$ purged needles and syringes. $S$. alga cell concentrations were 1 to $3 \times 10^{7}$ cells $/ \mathrm{mL}$ in all serum vials at $\mathrm{t}_{0} ; S$. putrefaciens cell concentrations were 2 to $4 \times 10^{7}$ cells $/ \mathrm{mL}$.

Solution Phase Analysis: U(VI) reduction was quantified by measuring U(VI) solution concentrations at several time points during the reaction. U(VI) concentrations were determined spectrophotometrically at $578 \mathrm{~nm}$ using the bromo-PDAP (2-(5-bromo-2-pyridylazo)-5-diethylaminophenol) method (Johnson and Florence 1971). Sample aliquots ranging from $30 \mu \mathrm{L}$ to $2.5 \mathrm{~mL}$ were passed through a $0.2 \mu \mathrm{m}$ filter and added to the appropriate amount of anaerobic water. One $\mathrm{mL}$ of complexing solution, $1 \mathrm{~mL}$ of buffer solution, $5 \mathrm{~mL}$ of ethanol, and $1 \mathrm{~mL}$ of bromo-PDAP solution $(0.05 \%$ in ethanol) were added to each diluted sample. Color was permitted to develop for $45 \mathrm{~min}$ and samples were immediately analyzed. Total soluble uranium and iron were measured using a Thermo Jarrell Ash inductively coupled plasma optical emission spectrophotometer (ICP-OES). Under these conditions it is reasonable to assume, and our data show, that all of the soluble uranium is U(VI) and all of the soluble iron is Fe(II), even in the presence of NTA.

Aqueous samples for ICP analysis were passed through a $0.2 \mu \mathrm{m}$ filter, acidified to $\mathrm{pH} 2$ with 0.5 $\mathrm{M} \mathrm{HCl}$ (1:4 dilution), and then sealed and stored in an anaerobic chamber until analysis. Fe(II) was 
quantified using the ferrozine colorimetric method at $562 \mathrm{~nm}$ (Stookey 1970); for dissolved Fe(II), $1 \mathrm{~mL}$ of filtered solution was added to $0.5 \mathrm{~mL}$ of $0.5 \mathrm{M} \mathrm{HCl}$ and then analyzed by the ferrozine method. To quantify $\mathrm{Fe}(\mathrm{II})$ production, $0.5 \mathrm{M} \mathrm{HCl}$ extractions were used to remove $\mathrm{Fe}$ (II) sorbed to the surface of ferrihydrite. A $0.75 \mathrm{~mL}$ aliquot of the suspension was added (unfiltered) to $0.75 \mathrm{~mL}$ of $0.5 \mathrm{M} \mathrm{HCl}$. These extractions were allowed to sit for at least $24 \mathrm{~h}$ before analysis.

Microscopy: "Biofilm" formation, extracellular polymeric substances, and spatial relationships between cells were observed using a Zeiss 510 Axioplan 2 confocal scanning laser microscope (CSLM) at the Stanford Center for Biofilm Research. Samples were carefully taken by a modified pipette from the bottom of the serum vial and placed on a microscope slide. A double labeling technique was used to determine spatial distribution of microbial cells and associated EPS (Decho and Kawaguchi 1999). Syto 83 (final concentration of $1.75 \mu \mathrm{M}$ ) (Molecular Probes) was used to stain cellular DNA and Alexa Fluor FITC Concanavalin A (final concentration of $2.5 \mu \mathrm{g} / \mathrm{L}$ ) (Molecular Probes), to stain the EPS.

Concanavalin A specifically binds to $\mathrm{D}(+)$ glucose and $\mathrm{D}(+)$ mannose groups on EPS. A cover-slip was placed on stained samples, sealed with silica gel (to maintain hydration), and allowed to incubate for 15 minutes. Three-dimensional images were immediately taken using CSLM at a pixel-pixel resolution of 1024x1024. An Argon laser at $488 \mathrm{~nm}$ wavelength (10-15\% laser intensity) was used for imaging EPS; a Helium-Neon laser was used to excite Syto 83. To minimize emission interference, DNA and EPS were imaged using the "Multi-track" configuration. Phase contrast images were also taken in order to record the location of the iron oxides relative to the microbial aggregates. High-resolution transmission electron microscopy (HRTEM) was used to view cells and the associated iron and uranium precipitates. Samples with associated precipitates were anaerobically embedded in hard-grade LR White resin and cured for $6 \mathrm{~h}$ at $60^{\circ} \mathrm{C}$. Hardened blocks were sectioned in an anaerobic glovebox using Leica UltraCut R microtome. Thin sections were observed at $200 \mathrm{kV}$ using a JEOL 2010 high-resolution transmission electron microscope. Mineral precipitates observed using HRTEM were also examined with lattice fringe analysis and energy dispersive spectroscopy (EDS).

Solid phase analysis: X-ray diffraction patterns were collected on samples to identify solid phase reaction products. Serum vials were vigorously shaken and vacuum filtered through a $0.2 \mu \mathrm{m}$ filter, washed twice with anaerobic DI water and dried in a $\mathrm{N}_{2}$ purged glovebox chamber overnight. Samples were mixed with anaerobic glycerol in the chamber and spread uniformly across a glass slide. Glycerol was used to minimize oxidation of uranium during XRD analysis (Hansen et al. 1996). Diffraction patterns of the solids were acquired with a Rigaku Geiger-flex powder diffractometer using $\mathrm{Cu} \mathrm{K} \alpha$ radiation.

\section{RESULTS and IMPLICATIONS}

\section{Uranyl and Fe(III) Reduction by $S$. alga and $S$. putrefaciens}

Both Shewanella alga strain BrY and Shewanella putrefaciens Strain CN32 reduced U(VI) over a period of $400 \mathrm{~h}$ under all conditions tested (Figure 1). A decrease in soluble U(VI) was apparent for both organisms within the first $10 \mathrm{~h}$ of reaction, and the overall reaction is well described $\left(\mathrm{R}^{2}=0.998\right.$ and 0.996 for $S$. alga and S. putrefaciens, respectively) by Monod kinetics, eqn. 4, with no growth (Figure 2).

$$
\mathrm{dT}_{\mathrm{U}(\mathrm{VI})} / \mathrm{dt}=-\mathrm{V}_{\max } \mathrm{T}_{\mathrm{U}(\mathrm{VI})} \mathrm{X} / \mathrm{K}_{\mathrm{m}}+\mathrm{T}_{\mathrm{U}(\mathrm{VI})}
$$

Uranyl reduction was accompanied by the formation of a gray precipitate that formed and was incorporated into aggregates made up of bacterial cells and their associated extracellular polymeric substances. X-ray diffraction of the aggregates, although exhibiting a high signal to noise ratio and broad diffraction peaks, was consistent with the pattern of uraninite $\left(\mathrm{UO}_{2}(\mathrm{~s})\right.$ (data not shown). Broad 
diffraction peaks are characteristic of biogenically produced uraninite (Fredrickson et al. 2000), including that formed by S. alga (Wielinga et al. 2000).

Uranyl reduction was not observed in control suspensions with heat killed cells or without lactate present as an electron donor (data not shown), and this is consistent with previous experiments demonstrating that reduction is a microbially driven process. Kinetic considerations dictate that $\mathrm{Fe}$ (II) produced by reduction of ferrihydrite likely has a lesser impact on $\mathrm{U}(\mathrm{VI})$ reduction relative to bacterial reduction (Fendorf et al. 2002). Loss of U(VI) and/or uranyl-carbonate complexes from solution due to sorption on ferrihydrite and/or cells was minimal. In suspensions containing ferrihydrite, between $3 \%$ and $6 \%$ of initial U(VI) was lost. Low U(VI) sorption is likely due to high levels of dissolved carbonate and limited retention of uranyl carbonate complexes (Duff and Amrhein 1996; Mason et al. 1997; Pratopo et al. 1990).

Iron(III) reduction was quantified by measuring soluble Fe(II) production (Figure 1). In all cases, $\mathrm{Fe}$ (III) in ferrihydrite (5 mmol Fe(III)/L initially) served as an electron acceptor for both $S$. alga and $S$. putrefaciens in the presence of U(VI). In suspensions containing ferrihydrite, $S$. alga reduced $81 \%$ and $S$. putrefaciens $68 \%$ of the total $\mathrm{Fe}(\mathrm{III})$ available over the $400 \mathrm{~h}$ reaction period.

\section{Simultaneous Reduction of U(VI) and Fe(III)}

Reduction of U(VI) was slightly inhibited when ferrihydrite was present as an alternate electron acceptor in systems inoculated with $S$. alga. In suspensions with only uranium, $S$. alga reduced $76 \%$ ( \pm $5 \%)$ of the uranyl over $400 \mathrm{~h}$. In suspensions amended with ferrihydrite, $S$. alga reduced only $58 \%( \pm$ $0 \%$ ) of the U(VI) present. Similarly, in suspensions inoculated with S. putrefaciens, $95 \%( \pm 1 \%)$ of the uranyl was reduced to U(IV) compared to $68 \%( \pm 1 \%)$ when suspensions were amended with ferrihydrite. Accordingly, rates of U(VI) reduction, calculated using a Monod kinetic expression, decreased when ferrihydrite was present in suspension. The U(VI) reduction rate $\left(\mu_{\max }\right)$ for $S$. alga decreased $25 \%$ from $180 \mathrm{mmol} \mathrm{U}(\mathrm{VI}) / \mathrm{h}$ without ferrihydrite to $135 \mathrm{mmol} \mathrm{U}(\mathrm{VI}) / \mathrm{h}$ with ferrihydrite. S. putrefaciens reduction rate $\left(\mu_{\max }\right)$ decreased $32 \%$ from $110 \mathrm{mmol} \mathrm{U}(\mathrm{VI}) / \mathrm{h}$ to $75 \mathrm{mmol} \mathrm{U}(\mathrm{VI}) / \mathrm{h}$ when ferrihydrite was present. These data are similar to those published by Wielinga et al (2000) who also observed retardation of microbial (S. alga) uranyl reduction by ferrihydrite, although the impact was more dramatic in the previous study. The extent of retardation varies between experiments conducted with the same microbe and nearly identical solution conditions; the single difference in solution conditions is the dissolved carbonate concentration. In this experiment, dissolved carbonate concentrations were $30 \mathrm{mM}$ equilibrated with an 80:20 $\mathrm{N}_{2}: \mathrm{CO}_{2}$ headspace, which are higher than carbonate concentrations in prior experiments (Wielinga et al 2000). As a consequence, reduction rates observed are slower. This may be explained by the observation that higher carbonate concentrations affect the rate of microbial reduction of uranyl (Phillips et al. 1995).

Concurrent reduction of U(VI) and Fe(III) in ferrihydrite by both $S$. alga and S. putrefaciens is observed in all conditions studied. Bacterially catalyzed electron transfer from lactate to $\mathrm{Fe}(\mathrm{III})$ and to $\mathrm{U}(\mathrm{VI})$ during four different phases of the reaction $(0$ to $24 \mathrm{~h}, 24$ to $72 \mathrm{~h}, 72$ to $144 \mathrm{~h}$, and 144 to $400 \mathrm{~h})$ are illustrated in Figure 3. Electron transfer was calculated using changes in U(VI) and Fe(II) solution concentrations, normalizing to a per-mole electron basis. Values were normalized to time $(\mathrm{mol} \cdot$ electrons $/ \mathrm{L} \cdot \mathrm{d})$, providing a quantitative measure of the relative microbial utilization of $\mathrm{U}(\mathrm{VI})$ and $\mathrm{Fe}(\mathrm{III})$ over the course of the reaction.

Neither $S$. alga or $S$. putrefaciens show an exclusive preference towards one electron acceptor but rather utilize both electron acceptors simultaneously. Throughout the course of the reaction, $S$. alga transfers an average of $31 \%$ of its electrons to U(VI) and $69 \%$ to Fe(III) ( $\pm 8.7 \%)$. Similarly, $S$. putrefaciens transfers $39 \%$ to $\mathrm{U}(\mathrm{VI})$ and $61 \%$ to ferrihydrite $( \pm 12.5 \%)$. The fraction of uranium and iron utilized does not dramatically change as metabolic activity progresses - throughout the experiments the two electron acceptors are utilized at a relatively consistent ratio (Figure $3 \mathrm{c}, \mathrm{d}$ ). This suggests that there is not a systematic change in preference as one electron acceptor is exhausted or becomes less available (due to $\mathrm{Fe}(\mathrm{II})$ sorption to ferrihydrite surfaces, for example). 
To understand how simultaneous reduction of two electron acceptors affects the metabolic capacity of a microbial population and to assess whether the same cells or different populations reduce $U$ and Fe, the overall metabolic activities of $S$. alga and $S$. putrefaciens were compared in solutions containing only $\mathrm{U}(\mathrm{VI})$ and solutions containing both $\mathrm{U}(\mathrm{VI})$ and $\mathrm{Fe}(\mathrm{III})$. Electron transfer capacity (i.e., the number of electrons transferred from lactate to an electron acceptor) was used as an indication of overall metabolic activity; again activity is calculated at four distinct periods during the reaction.

Temporal changes in $\mathrm{U}$ and Fe utilization by $S$. alga and $S$. putrefaciens demonstrate the effect of $\mathrm{Fe}(\mathrm{III})$ amendments on overall metabolic activity (Figure 4). While ferrihydrite inhibits U(VI) reduction, a more dramatic effect of ferrihydrite is an increase in overall metabolic activity of the microbial population - more electrons are transferred when both $\mathrm{Fe}(\mathrm{III})$ and $\mathrm{U}(\mathrm{VI})$ are present. This trend is apparent in both $S$. alga and $S$. putrefaciens suspensions, although it is particularly dramatic in $S$. alga suspensions. For example, after $72 \mathrm{~h}$ of reacting, $S$. alga transfers $0.07 \mathrm{mmol}$-electrons per day to U(VI). When $S$. alga has both iron and uranium available, $0.04 \mathrm{mmol}$-electrons/d are transferred to U(VI) and $0.15 \mathrm{mmol}-\mathrm{electrons} / \mathrm{d}$ to $\mathrm{Fe}(\mathrm{III})$ (Figure $4 \mathrm{a}$ ), increasing the overall electron transfer rate $172 \%$.

Similarly, S. putrefaciens transfers $0.32 \mathrm{mmol}$-electrons/d to U(VI) (when present alone) but when ferrihydrite is introduced, an additional $0.35 \mathrm{mmol} / \mathrm{d}$ of electrons are transferred to ferrihydrite (Figure $4 \mathrm{~b})$. Thus, ferrihydrite increases the overall metabolic activity of $S$. putrefaciens by $115 \%$. This increase in metabolic capacity is not observed until after $24 \mathrm{~h}$ of reaction. Subsequent to this time, the increase in metabolic activity occurs throughout the course of reaction for both microbes. On average, ferrihydrite increases the metabolic capacity $129 \%$ for S. alga and $66 \%$ for $S$. putrefaciens.

\section{Exopolysaccharide Production and Biofilm Formation}

Confocal microscopy reveals that $S$. alga forms dense cell aggregates that develop as part of thick biofilms. Evidence of biofilm formation is apparent within the first $24 \mathrm{~h}$ of the reaction; cell-cell and cellmineral associations are observed. After $3 \mathrm{~d}$, very few planktonic cells are present. Bacterial cells, extracellular polysaccharides, and mineral solids, are visible in cell aggregates/biofilms in all experimental conditions studied. Direct cell-to-cell association is observed as multi-layered biofilm structures develop and a tightly held "capsule" EPS, evenly distributed within the biofilms, appears to act as the bonding agent for the aggregate.

In solutions containing only U(VI), aggregates of $S$. alga form within $24 \mathrm{~h}$ of inoculation (Figure 5a). In solutions containing ferrihydrite, similar cell aggregates form within the same time frame; ferrihydrite particles are observed at the center of all cell aggregates (Figure 6a). Fluorescent and phase contrast images collected simultaneously show rapid attachment of $S$. alga to the surface of ferrihydrite; particles are covered in at least a monolayer of microbial cells. After $3 \mathrm{~d}$, ferrihydrite particles are coated in a multi-layered biofilm 5-100 cells thick. In addition to extensive cell-mineral attachment, cell-cell attachment is observed in the outer layers of the biofilm. Although it is believed that most Shewanella strains do not require direct contact with an iron oxide surface in order to utilize the substrate as an electron acceptor (Lovley and Woodward 1996; Nevin and Lovley 2000; Newman and Kolter 2000), direct contact with the mineral surface is certainly favorable. It is not surprising then, given chemical data presented here, that $S$. alga shows a strong preference to rapidly attach to ferrihydrite surfaces.

Strain $S$. putrefaciens shows substantially different attachment and biofilm formation behavior than $S$. alga. Although $S$. putrefaciens produces EPS that facilitates biofilm formation, cells do not form densely packed cell aggregates/biofilm. S. putrefaciens produces extensive but loosely held EPS, commonly referred to as "gel" EPS, in which cells are suspended (Figure 5b). In these cell-EPS suspensions/aggregates, very little cell-to-cell contact is observed. In most cases, cells are separated by between 2 to $10 \mu \mathrm{m}$. Not all cells are associated with the gel-like EPS; single planktonic cells can be seen throughout the duration of the reaction. The appearance of a multi-layered, structured biofilm is not observed until approximately $72 \mathrm{~h}$ of reaction time.

In the first 24 hours, no cell-cell attachment or cell-mineral association is seen and only very small amounts of EPS are associated with single cells or floating freely in solution. Evidence of loosely held cell-EPS aggregates is not observed until $72 \mathrm{~h}$ of reaction time. Over the course of the reaction, more 
cells become associated with cell aggregates, but planktonic cells remain prevalent. In suspensions containing ferrihydrite, cell to mineral attachment begins to occur within the first $24 \mathrm{~h}$. After $3 \mathrm{~d}$, more extensive cell attachment to ferrihydrite is seen, and loosely packed cell-EPS aggregates incorporating ferrihydrite are observed (Figure $6 \mathrm{~b}$ ). Some ferrihydrite particles are coated with a densely packed monolayer of cells. After $16 \mathrm{~d}, S$. putrefaciens cells coated all available ferrihydrite surfaces and extensive multi-layer biofilm formation is observed.

\section{$U$ and Fe Reduction Kinetics}

Uranium and iron reduction data was analyzed using chemical and diffusion kinetic models including: (i) Monod (ii) zero-order (iii) first-order (iv) second-order (v) parabolic diffusion and (vi) Elovich equations. The most accurate rate expression was determined by the correlation coefficient of a linear fit; all accepted rate expressions had $\mathrm{R}^{2}>0.90$.

$\mathrm{U}(\mathrm{VI})$ reduction by $S$. alga and $S$. putrefaciens is well described by a Monod kinetic expression (Figure 2), confirming that $S$. alga and S. putrefaciens are metabolizing U(VI) at a rate consistent with a $\mu_{\max }$ of $110 \mu \mathrm{M} / \mathrm{h} /$ cells $/ \mathrm{mL}$ and a $\mathrm{K}_{\mathrm{s}}$ of $370 \mu \mathrm{M}$ for $\mathrm{U}(\mathrm{VI})$ reduction by $S$. putrefaciens described in Liu et al. (2002). When uranyl was present as the only available electron acceptor, measured reduction data matched predicted trends (adjusted for cell concentration) with an $\mathrm{R}^{2}$ of 0.996 . When Fe was present as an alternative electron acceptor, predicted trends were also in agreement with measured data $\left(\mathrm{R}^{2}\right.$ of 0.980). Uranium reduction by $S$. alga was compared to $\mu_{\max }$ and $\mathrm{K}_{\mathrm{s}}$ values measured by $\mathrm{Y}$. Gorby (personal communication) as reported in Fendorf et al. (2002). Predicted data, adjusted for cell concentration, fit measured data with an $\mathrm{R}^{2}$ of 0.998 with only uranium and 0.998 with uranyl and ferrihydrite combined.

Unlike U(VI) reduction, neither $S$. alga nor $S$. putrefaciens Fe(III) reduction data fit a first-order or Monod kinetic model. The parabolic diffusion model best described the temporal variation in Fe(II) concentration (Figure 7; $\mathrm{R}^{2}$ of 0.90 (S. alga) and 0.94 (S. putrefaciens)), suggesting that diffusion is an important rate-limiting factor. The parabolic diffusion model was designed to predict ion diffusion into a cylinder and has been used to describe numerous transport-limited processes in soil chemical environments (Sparks 1995).

\section{Simultaneous Reduction and Increased Metabolic Capacity.}

Competition between metabolic substrates has been studied in a number of systems, for example, metal reduction, TCE dehalogenation and denitrification (Gerritse et al. 1999; Townsend and Suflita 1997; Blakeney et al. 2000; Carter et al. 1995; DiChristina 1992; Krekeler and Cypionka 1995; Oremland et al. 1999). Simultaneous reduction by dissimilatory metal reducing bacteria has been observed previously (Blakeney et al. 2000; DiChristina 1992; Oremland et al. 1999); various postulates that may be relevant to this study have been made regarding operating mechanisms including low substrate-specific enzymes, constitutive enzymes, shared components of respiratory pathways, and abiotic electron shuttling.

Enzymes that demonstrate low substrate specificity have been found in S. putrefaciens and can catalyze reactions for more than one substrate (Blakeney et al., 2000). However, it is unlikely that a low substrate specific enzyme could account for the reduction patterns observed here. While these enzymes can result in simultaneous reduction of multiple substrates, they cannot explain the increase in metabolic capacity of the microbial population. Other authors have suggested that constitutive enzymes may explain simultaneous reduction of two electron acceptors (Oremland et al., 1999). Because constitutive enzymes are typically expressed at low levels, again, this does not likely explain the observed increase in metabolic activity. While we cannot definitively eliminate these explanations, they are not likely explanations for the observed results, as discussed below.

Substrates that share portions of the respiratory chain represent a reasonable explanation for both simultaneous reduction and the increase in metabolic activity observed in these studies. A shared respiratory chain creates a branching point at which components could deliver electrons to more than one electron acceptor. DiChristina (1992) attributed simultaneous reduction of nitrogen oxides and Fe(III) by 
S. putrefaciens strain 200 to shared respiratory chain components. Ferric iron was believed to serve as a secondary sink for electrons after $\mathrm{NO}_{3}{ }^{-}$or $\mathrm{NO}_{2}{ }^{-}$reductase sites were fully saturated (DiChristina 1992). This results in simultaneous reduction of two substrates and could also result in an increase in overall metabolic capacity. Again, this explanation cannot be eliminated with the data collected in these studies.

Abiotic redox reactions must also be considered in the redox chemistry of these studies. While soluble $\mathrm{Fe}(\mathrm{II})$ is a poor reductant of $\mathrm{U}(\mathrm{VI}), \mathrm{Fe}(\mathrm{II})$ sorbed to the surface of ferrihydrite is a more facile reductant (Liger et al. 1999). However, it is unlikely that Fe(II) reduction of U(VI) is an active process in these systems for two reasons. Rates of abiotic reduction of U(VI) by Fe(II), even when Fe(II) is sorbed, are slower than microbially driven reduction (Fendorf et al. 2002). In addition, U(VI) reduction by $S$. alga and $S$. putrefaciens in the presence of ferrihydrite shows a strong correlation $\left(\mathrm{R}^{2}=0.998\right.$ and 0.996 , respectively) to reduction rates predicted by the Monod expression, a trend that would not be expected if abiotic reduction was a dominant process. A sequence of experiments designed to test the occurrence of Fe(III) reduction by biologically produced U(IV) have been conducted in our lab. Preliminary results do not show evidence for Fe(III) reduction by U(IV).

\section{Development of Biofilms Microenvironments}

Biofilm formation may be the mechanism driving simultaneous reduction of iron and uranium. CSLM images reveal that the large majority of cells in this system are living in cell aggregates/biofilms. Solution phase data and kinetic analysis show that (i) metabolic activity is being inhibited, an observation that is well documented in biofilms and (ii) diffusion is rate limiting, another factor shown to be important in biofilms. As microbial biofilms develop, metabolic activity drives the formation of steep chemical gradients resulting in the formation of microenvironments within the biofilm. Cells are thus compelled to adapt their operative metabolism to substrates available within their local microenvironment; in some instances, preference may lead to electron acceptor selection.

Our expectations for the presence of chemical gradients within the observed S. putrefaciens and S. alga biofilms provide an interesting explanation for data collected in these studies. When only U(VI) is present, metabolic activity decreases towards the center of the aggregate. When ferrihydrite is present, aggregates form around the particles providing cells deep in the aggregates with an electron acceptor. Thus, cells that were metabolically less active towards the interior of the biofilm due to a steep U(VI) gradient are active when ferrihydrite is present. Therefore, substrate utilization by $S$. alga and $S$. putrefaciens may be due to electron acceptor availability. 


\section{REFERENCES}

Allan VJM, Macaskie LE, Callow ME. 1999. Development of a pH gradient within a biofilm is dependent upon the limiting nutrient. Biotechnology Letters 21:407-413.

Balch WE, Fox GE, Magrum LJ, Woese CR, Wolfe R. 1979. Methanogens: A re-evaluation of a unique biological group. Microbiological Reviews 43:260-296.

Barton LL, Choudhury K, Thomson BMSh, K., Groffman AR. 1996. Bacterial reduction of soluble uranium: The first step in in situ immobilization of uranium. Radioactive Waste Management and Environmental Restoration 20:141-151.

Blakeney MD, Moulaei T, DiChristina TJ. 2000. Fe(III) reduction activity and cytochrome content of Shewanella putrefaciens grown on ten compounds as sole electron acceptor. Microbiology Research 155:87-94.

Caccavo FJ, Blakemore RP, Lovley DR. 1992. A hydrogen oxidizing, Fe(III)-reducing microorganisms from the Great Bay Estuary, New Hampshire. Applied and Environmental Microbiology 58:3211.

Caccavo FJ, Das A. 2002. Adhension of dissimilatory Fe(III)-reducing bacteria to Fe(III) minerals. Geomicrobiology 19:161-177.

Caccavo FJ, Frolund B, Kloeke FvO, Nielsen PH. 1996. Deflocculation of activated sludge by the dissimilatory Fe(III)-reducing bacterium Shewanella alga Strain BrY. Applied and Environmental Microbiology 62:1487-1490.

Carter JP, Hsiao YS, Spiro S, Richardson DJ. 1995. Soil and sediment bacteria capable of aerobic nitrate respiration. Applied and Environmental Microbiology 61(8):2852-2858.

Chen X, Stewart PS. 1996. Chlorine penetration into artificial biofilm is limited by a reaction-diffustion interaction. Environmental Science and Technology 30:2078-2083.

Cornell RM, Schwertman U. 1996. The Iron Oxides. Weinheim: VCH Verlagsgesellschaft mbH. 573 p.

Das A, Caccavo FJ. 2000. Adhesion of the dissimilatory Fe(iII)-reducing bacterium Shewanella alga BrY to crystalline Fe(III) oxides. Current Microbiology 42:151-154.

Decho AW, Kawaguchi T. 1999. Confocal imaging of the in-situ natural microbial communities and their extracellular polymeris secretions using nanoplast resin. BioTechniques 27:1246-1252.

DiChristina TJ. 1992. Effects of nitrate and nitrite on dissimilatory iron reduction by Shewanella putrefaciens 200+. Journal of Bacteriology 174(6):1891-1896.

Duff MC, Amrhein PM. 1996. U(VI) adsorption on geothite and soil in carbonate solutions. Soil Science Society of America Journal 60:1393-1400.

Fendorf S, Wielinga B, Hansel CM. 2002. Operative pathways of chromate and uranyl reduction within soils and sediments. In press.

Fredrickson JK, Zachara JM, Kennedy DW, Duff MC, Gorby YA, Li SW, Krupka KM. 2000. Reduction of U(VI) in goethite (alpha-FeOOH) suspensions by a dissimilatory metal-reducing bacterium. Geochimica et Cosmochimica Acta 64(18):3085-3098.

Geesey G, Jang L. 1990. Extracellular polymers for metal binding. In: Ehrlich HL, Brierley CI, editors. Microbial Mineral Recovery. New York: McGraw Hill. p 223-247.

Gerritse J, Drzyzga O, Kloestra G, Keijmel M, Weirsum LP, Hutson R, Collins MD, Gottschal JC. 1999. Influence of Different Electron Donors and Accpetors on Dehalorespiration of Tetrachloroethene by Desulfitobacterium frappieri TCE1. Applied and Environmental Microbiology 65(12):5212-5221.

Hansen HCB, Koch CB, Nancke-Krogh H, Borggaard OK, Sorensen J. 1996. Abiotic nitrate reduction to ammonium: key role of Green Rust. Environmental Science and Technology 30(6):2053-2056.

Heron G, Tjell JC, Christensen TH. 1994. Oxidation capacity of aquifer sediment. In: Hinchee RE, Alleman BC, Hoeppel RE, Miller RN, editors. Hydrocarbon Remediation: Lewis Publishers.

Johnson DA, Florence TM. 1971. Spectrophotometric determination of uranium(VI) with 2-(5-bromo-2-pyridylazo)5-diethylaminophenol. Analytical Chimica Acta 53:73-79.

Kinniment SL, Wimpenny JWT. 1992. Measurements of the distribution of adenylate concentration and adenylate energy-charge across Pseudomonas aeruginosa biofilms. Applied and Environmental Microbiology 58:1629-1635.

Krekeler D, Cypionka H. 1995. The preferred electron-acceptor of Desulfovirbrio desulfuricans CSN. FEMS Microbiology Ecology 17(4):271-277.

Liger E, Charlet L, Van Cappellen P. 1999. Surface catalysis of uranium(VI) reduction by iron(II). Geochimica et Cosmochimica Acta 63(19/20):2939-2955.

Lion LW, Shuler ML, Hsieh KM, Ghiorse WC. 1988. Trace metal interations with microbial biofilms in natural and engineered systems. CRC Critical Reviews in Environmental Control 17(4):273-306. 
Liu C, Zachara JM, Fredrickson JK, Kennedy DW, Dohnalkova A. 2002. Modeling inhibition of the bacterial reduction of U(VI) by beta-MnO2. Environmental Science and Technology 36:1452-1459.

Lovely DR, Widman PK, Woodward JC, Phillips EJP. 1993. Reduction of uranium by cytochrome c3 of Desulfovibrio vulgaris. Applied and Environmental Microbiology 59:3572-3576.

Lovley DR. 1991. Dissimilatory Fe(III) and Mn(VI) reduction. Microbiological Reviews 55(2):259-287.

Lovley DR, Phillips EJP. 1988. Novel mode of microbial energy metabolism: organic carbon oxidation coupled to dissimilatory reduction of iron or manganese. Applied and Environmental Microbiology 54:1472-1480.

Lovley DR, Phillips EJP. 1992a. Bioremediation of uranium contamination with enzymatic uranium reduction. Applied and Environmental Microbiology 58:850-856.

Lovley DR, Phillips EJP. 1992b. Reduction of uranium by Desulfovibrio desulfuricans. Environmental Science and Technology 26:2228-2234.

Lovley DR, Phillips EJP, Gorby Y. 1991. Microbial reduction of uranium. Nature 350:413-416.

Lovley DR, Woodward JC. 1996. Mechanisms for chelator stimulation of microbial Fe(III)-oxide reduction. Chemical Geology 132:19-24.

Mason CFW, Turney WR, Thompson BM, Lu N, Longmire PA. 1997. Carbonate leaching of uranium from contaminated soils. Environmental Science and Technology 31:2707-2711.

Mathews CK, van Holde KE. 1990. Biochemistry. Redwood City: The Benjamin/Cummings Publishing Company. $1129 \mathrm{p}$.

Nealson KH, Saffarini D. 1994. Iron and manganese in anaerobic respiration: Environmental Significance, Physiology, and Regulation. Annual Reviews in Microbiology 48:311-343.

Nevin KP, Lovley DR. 2000. Potential for nonenzymatic reduction of Fe(III) via electron shuttling in subsurface environments. Environmental Science and Technology 34:2472-2478.

Newman DK, Kolter R. 2000. A role for excreted quinones in extracellular electron transfer. Nature 405:94-97.

Oremland RS, Switzer Blum J, Bindi AB, Dowdle PR, Herbel M, Stolz JF. 1999. Simultaneous reduction of nitrate and selenate by cell suspensions of selenium-respiring bacteria. Applied and Environmental Microbiology 65(10):4385-4392.

Phillips EJP, Landa ER, Lovley DR. 1995. Remediation of uranium contaminated soils with bicarbonate extraction and microbial U(VI) reduction. Journal of Industrial Microbiology 14:203-207.

Pratopo MI, MOriyama H, Higasji K. 1990. Carbonate complexation of neptunium (IV) and analagous complexation of groundwater uranium. Radiochimica Acta 52/53:487-493.

Ryden JC, Syers JK, Tillman RW. 1987. Inorganic anion sorption and interactions with phosphate sorption by hydrous ferric ozide gel. Journal of Soil Science 38:211-217.

Schramm A, De Beer D, Gieseke A, Amann R. 2000. Microenvironments and distribution of nutrifying bacteria in a membrane-bound biofilm. Environmental Microbiology 2:680-686.

Sparks DL. 1995. Environmental Soil Chemistry. San Deigo: Academic Press, Inc. 267 p.

Stookey LL. 1970. Ferrozine - A new spectrophotometric reagent for iron. Anal. Chem 42:779-781.

Townsend GT, Suflita JM. 1997. Influence of sulfur oxyanions on reductive dehalogenation activities in Desulfomonile tiedjei. Applied and Environmental Microbiology 63:3594-3599.

Vroom JM, DeGrauw KJ, Gerritsen HC, Bradshaw DJ, Marsh PD, Watson GK, Birmingham JJ, Allison C. 1999. Depth penetration of detection of $\mathrm{pH}$ gradients in biofilms by two-photon excitation microscopy. Applied and Environmental Microbiology 65:3502-3511.

Wielinga B, Bostick B, Hansel CM, Rosenzweig RF, Fendorf SE. 2000. Inhibition of bacterially promoted uranium reduction: Ferric (hyrdr)oxides as competitive electron acceptors. Environmental Science and Technology $34: 2190-2195$. 


\section{FIGURES}
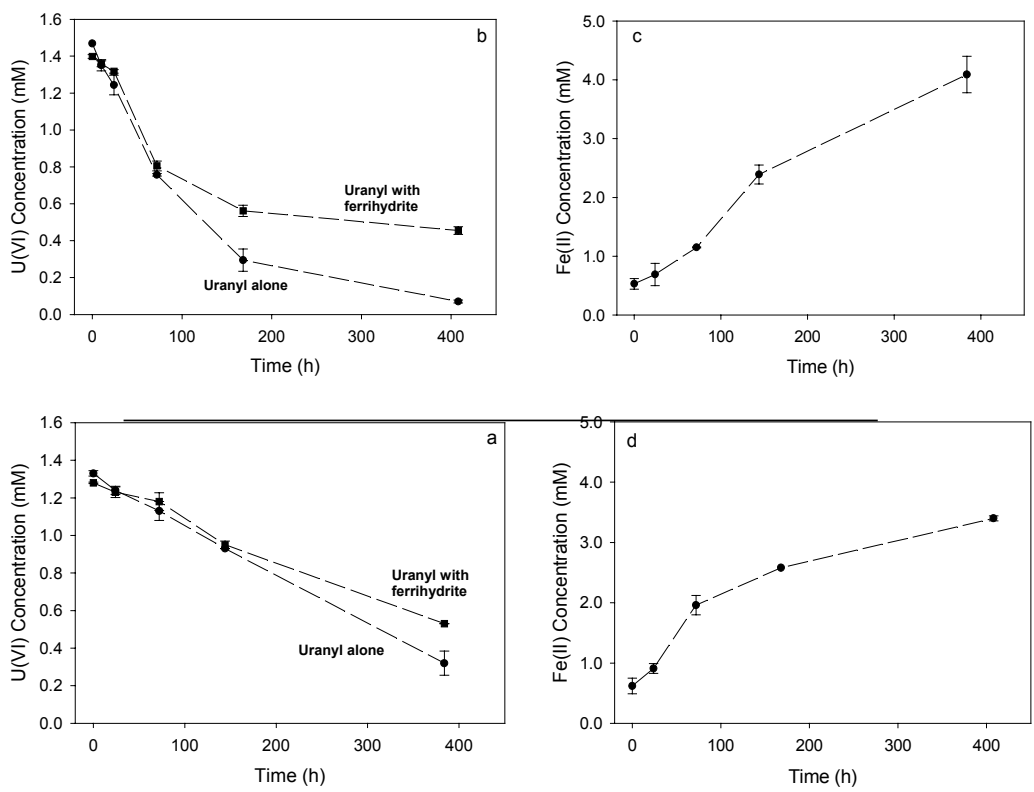

Figure 1. U(VI) reduction by (a) S. alga and (b) S. putrefaciens. Dashed line represents U(VI) when ferrihydrite is present; solid line, when ferrihydrite is not present. Total extractable Fe(II) production by (c) $S$. alga and (d) S. putrefaciens. Error bars represent standard deviation of duplicate samples. 

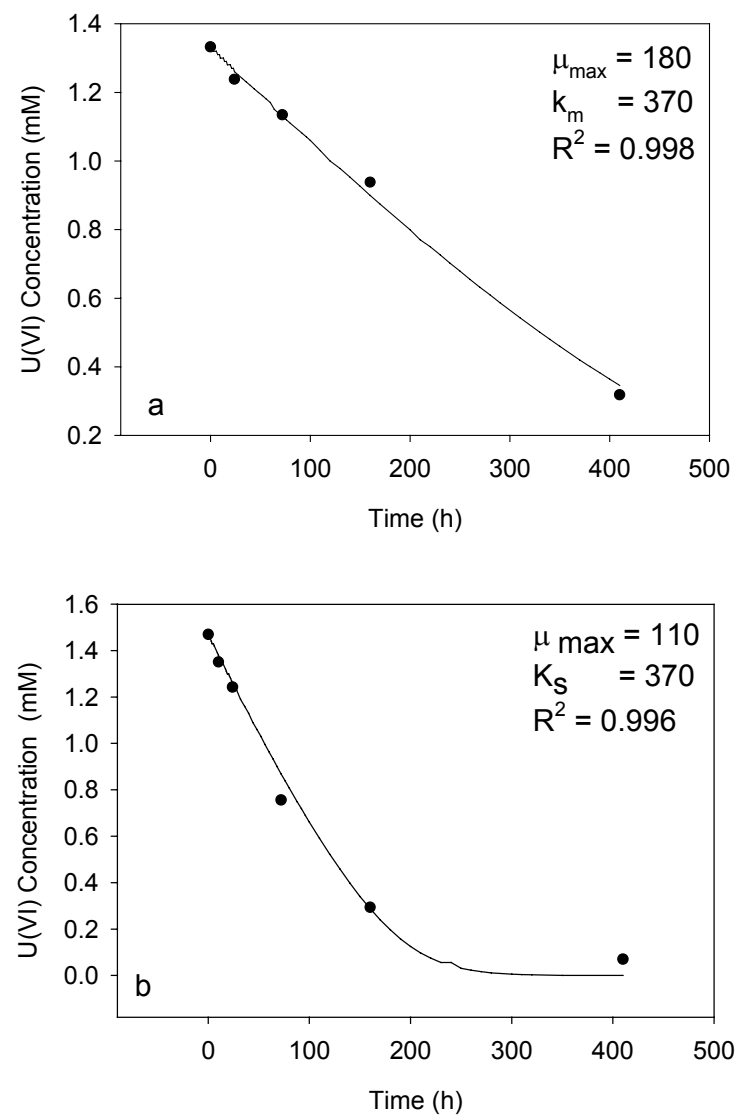

Figure 2. Measured U(VI) reduction data fit to Monod no-growth kinetic expression (a) $S$. alga (b) $S$. putrefaciens. 

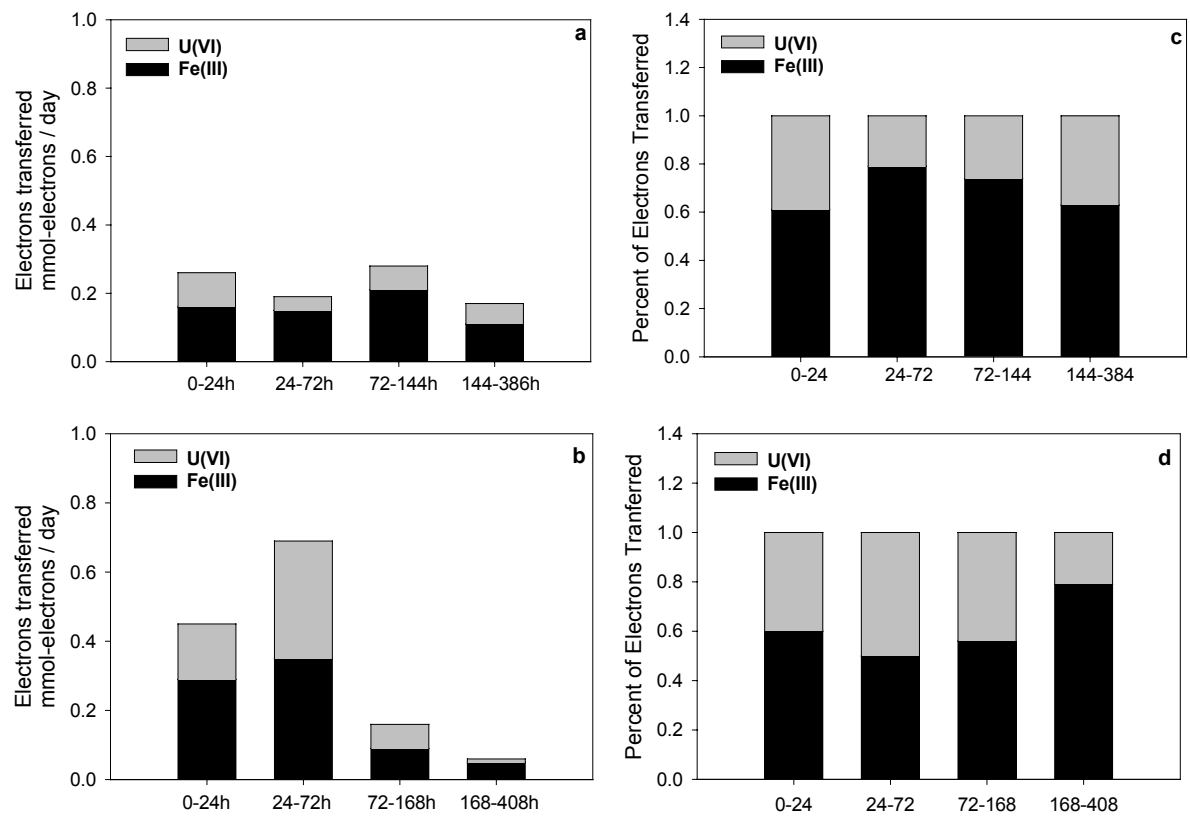

Figure 3. Utilization of U(VI) and Fe(III) by S. alga and S. putrefaciens; U and Fe present concurrently. Bars represent average number of electrons transferred to U(VI) and Fe(III) during designated portion of the reaction period, normalized to 24 hours. (a) $S$. alga (b) $S$. putrefaciens. In c and d, data expressed in percent of total electrons transferred by (c) $S$. alga (d) S. putrefaciens. 

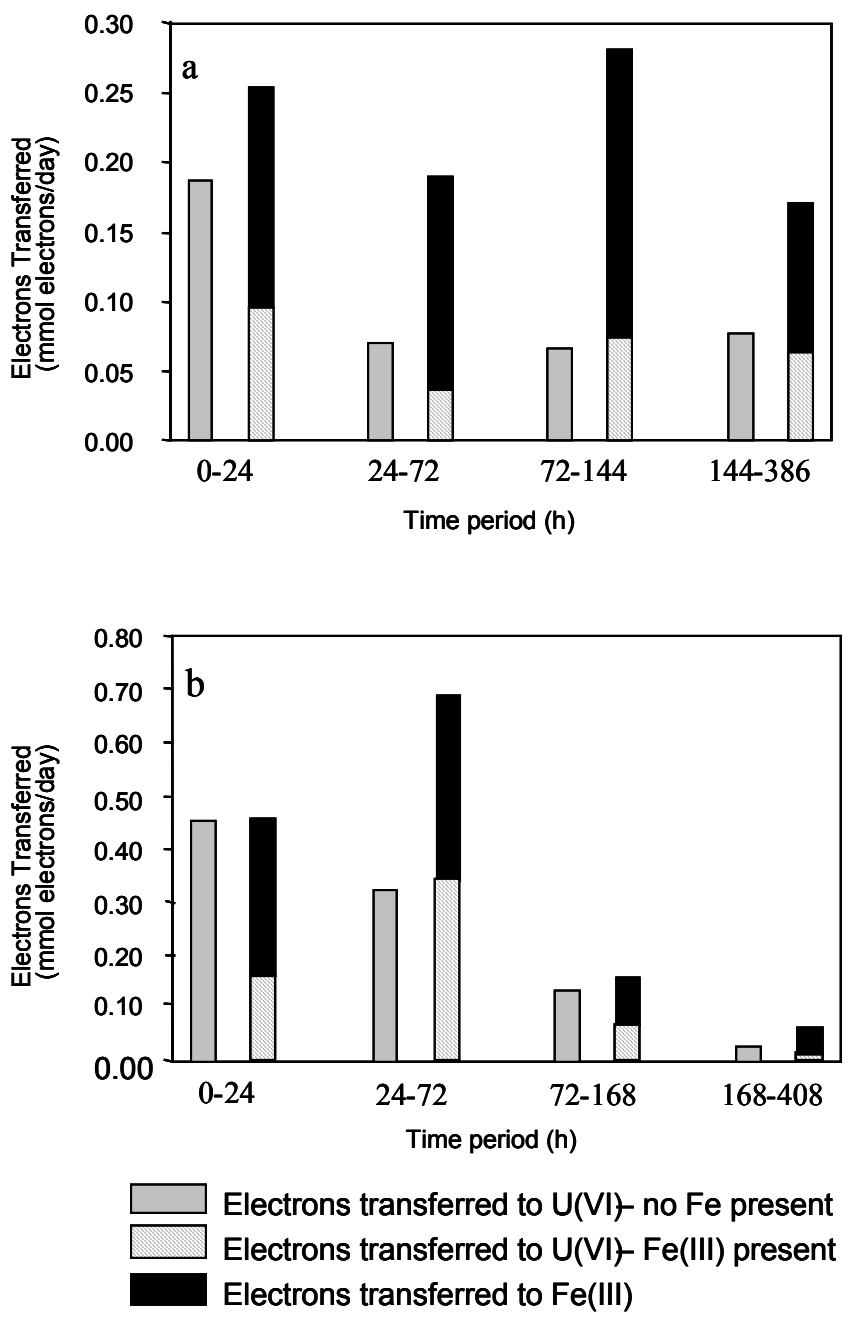

Figure 4. Effect of multiple electron acceptors on overall metabolic capacity of the cell population (a) $S$. alga (b) $S$. putrefaciens. Bars represent the number of electrons transferred to U(VI) or Fe(III) during a defined period of the reaction, normalized to 24 hours; $U$ and Fe present concurrently. 

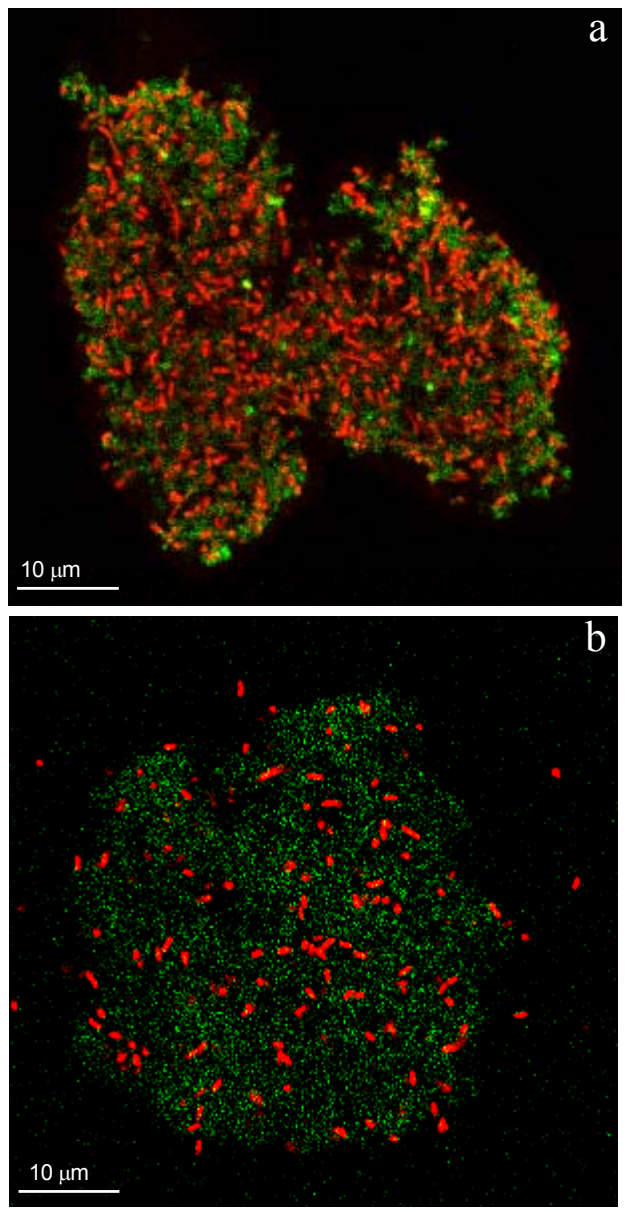

Figure 5. CSLM image of a slice through (a) a tightly held aggregate of $S$. alga cells; after 3 days with only U(VI) present (b) a loosely held aggregate of $S$. putrefaciens cells after 7 days with only U(VI) present. Cells stained red: Syto 83; EPS stained green: Alexa Fluor Concanavalin A. 

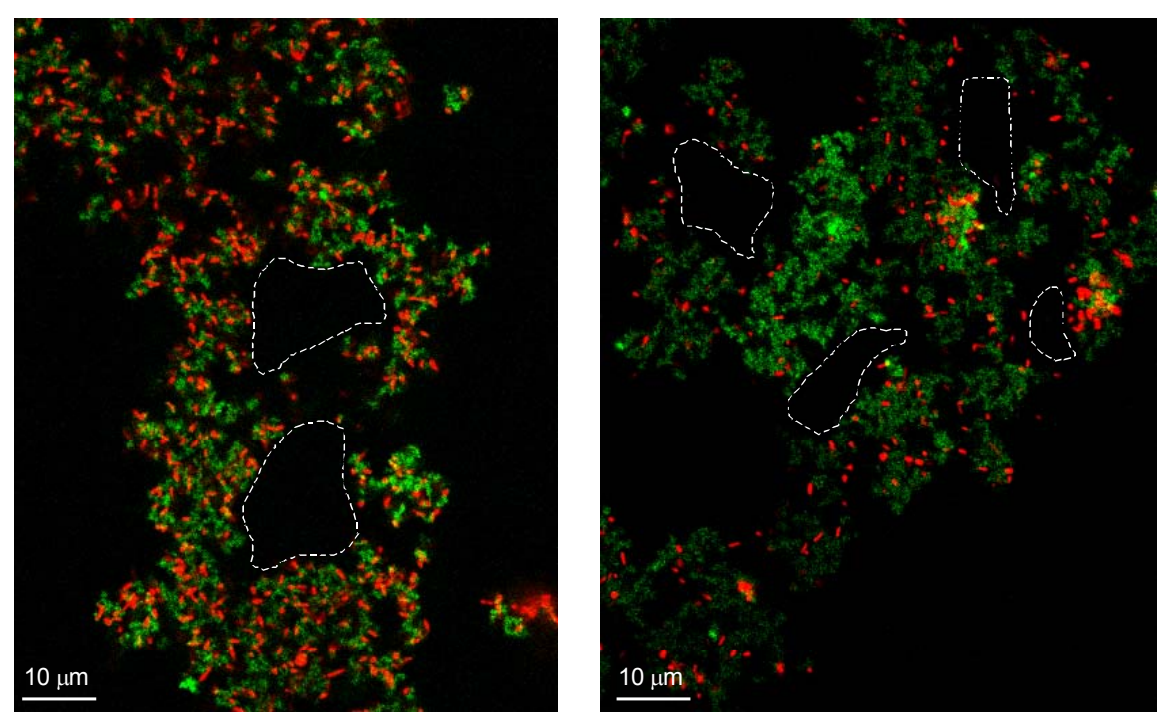

Figure 6. CSLM image of a slice through (a) S. alga and (b) S. putrefaciens cell aggregates formed around ferrihydrite particles (denoted by white dashed line). Cells stained red: Syto 83; EPS stained green: Alexa Fluor Concanavalin A. 

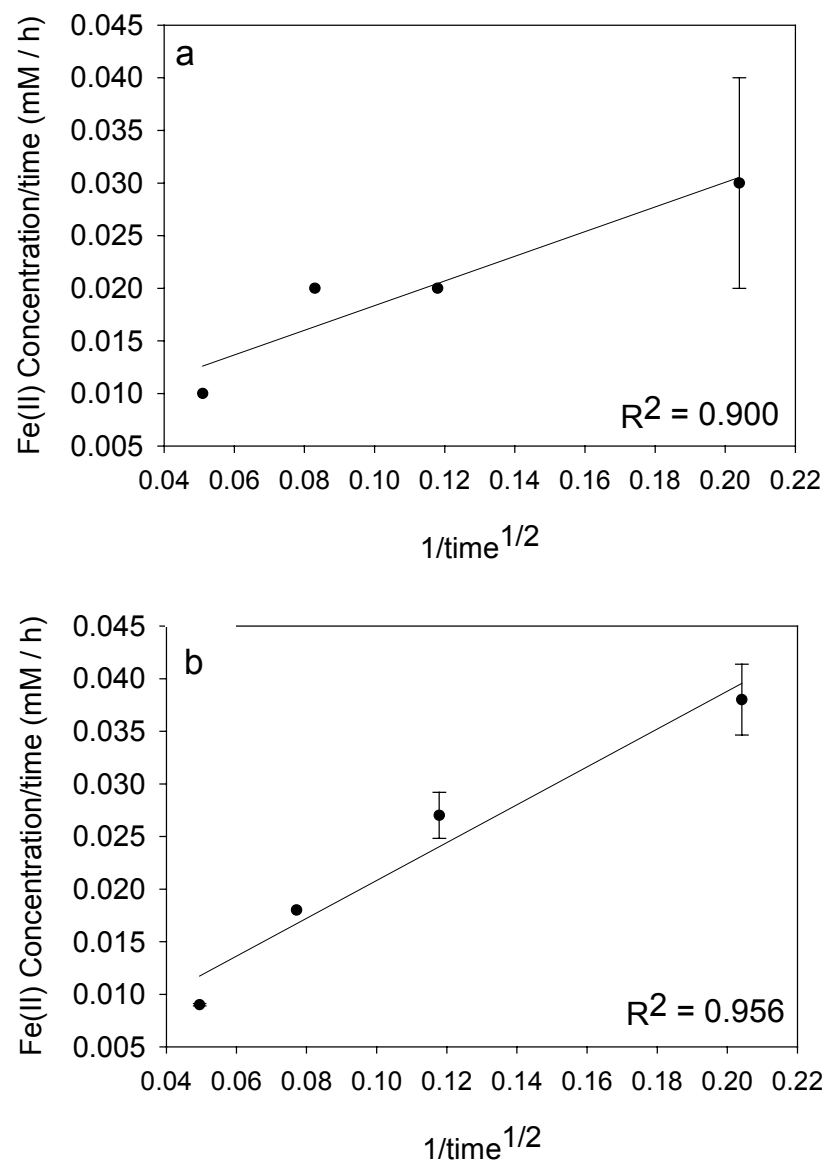

Figure 7. Measured $\mathrm{Fe}(\mathrm{II})$ production data fit to a parabolic diffusion kinetic expression; $\mathrm{U}$ and $\mathrm{Fe}$ present concurrently. (a) S. alga (b) S. putrefaciens. Error bars represent standard deviation of duplicate samples. 